\title{
Adaptation and validation of the instrument Positions on the Nursing Process ${ }^{1}$
}

\author{
Erika de Souza Guedes ${ }^{2}$ \\ Regina Marcia Cardoso de Sousa ${ }^{3}$ \\ Ruth Natalia Teresa Turrini ${ }^{4}$ \\ Valéria Troncoso Baltar ${ }^{5}$ \\ Diná de Almeida Lopes Monteiro da Cruz ${ }^{3}$
}

\begin{abstract}
Objective: estimate the psychometric properties in the adaptation of the instrument Positions on Nursing Diagnosis to assess nursing staff members' attitudes towards the nursing process. Method: methodological study with a non-probabilistic sample of 973 nursing assistants and 632 baccalaureate nurses from 35 hospitals and outpatient clinics affiliated with the São Paulo State Health Secretary. The validity of the 20-items instrument was checked through confirmatory factor analysis, which identified a more generally secondary-level factor, constituted by the three classical attitude factors. Reliability corresponded to 0.954 for the total instrument. Results: the validity and reliability of the instrument Posições sobre o Processo de Enfermagem are appropriate. Conclusions: further research is needed to verify whether the items behave differently according to the respondent's professional category and to verify the instrument's behavior when applied to student samples.
\end{abstract}

Descriptors: Nursing Process; Attitudes; Questionnaires.

\footnotetext{
${ }^{1}$ Paper extracted from Master's Thesis "Atitudes do pessoal de enfermagem relacionadas ao processo de enfermagem" presented to Escola de Enfermagem, Universidade de São Paulo, São Paulo, SP, Brazil. Supported by Fundação de Amparo à Pesquisa do Estado de São Paulo (FAPESP) process \# 2010/02985-6 and by Conselho Nacional de Desenvolvimento Científico e Tecnológico (CNPq), process \# 481728/2009-0. 2 Doctoral Student, Escola de Enfermagem, Universidade de São Paulo, São Paulo, SP, Brazil.

${ }^{3} \mathrm{PhD}$, Full Professor, Escola de Enfermagem, Universidade de São Paulo, São Paulo, SP, Brazil.

${ }^{4} \mathrm{PhD}$, Professor, Escola de Enfermagem, Universidade de São Paulo, São Paulo, SP, Brazil.

5 PhD, Adjunct Professor, Departament of Epidemiology and Biostatistics, Universidade Federal Fluminense, Niterói, RJ, Brazil.
} 


\section{Introduction}

In response to COFEN Resolution 358/2009(1), many health institutions mobilized to put in practice the Nursing Care Systemization (NCS). This process can be considered an innovation to the extent that planned changes are needed, aimed at improving nursing care delivery and registration systems, and individuals who participate in the set-up of the innovation perceive the process as something new which they need to adapt to ${ }^{(2)}$. The change involves factors related to knowledge, attitudes and behaviors towards the intended innovation ${ }^{(3)}$.

Attitudes refer to personal disposition to approach or take distance from an idea or concept, involve affection, predispose to action and, hence, influence behavior ${ }^{(4)}$. Disposition regarding NCS relates to attitudes in favor of or against the nursing process (NP). It is important to study factors that can interfere in the implementation and maintenance of NCS in clinical practice, whether related to the institutional environment or the nursing professionals.

In nursing literature, no consensus exists yet on the definition of expressions like NP and NCS. The definition of these terms depends on the adopted reference framework, the objective and the application area(5). In this study, the NP is defined as an instrument that provides a systematic guide to develop a style of thinking to direct the clinical judgments needed for nursing care $^{(6)}$. The terms NP and NCS will be used as synonyms.

The aim in this study was to adapt the instrument Positions on Nursing Diagnosis( ${ }^{(7)}$, a questionnaire that was originally developed to assess baccalaureate nurses or nursing students' attitudes towards the nursing diagnosis concept. The adaptation made for this study was the replacement of the nursing diagnosis by the NP concept. Despite the lack of available information on its development process, the Positions on Nursing Diagnosis $^{(7)}$ was presented at the tenth NANDA-I conference in $1992^{(7)}$. The instrument consists of 20 pairs of adjectives; one of the adjectives in each pair represents an attitude in favor of the concept and the other against it. Each pair is separated by seven equidistant points and respondents are expected to mark one of the points, according to the greater or lesser proximity between their attitude and one of the adjectives in each pair ${ }^{(8)}$. The Positions on Nursing Diagnosis(7) was submitted to the adaptation process to Portuguese language ${ }^{(8)}$. In a sample of 400 baccalaureate nurses and nursing students, reliability, estimated according to Cronbach's alpha, corresponded to 0.94 . Validity was estimated by comparing the scores before and after a nursing diagnosis course, in a sample of 100 baccalaureate nurses, and by applying correlation analysis with a general statement on the extent to which the respondent was in favor of the nursing diagnosis concept. Scores significantly improved after the course and a positive correlation was found with the general statement ${ }^{(8)}$. These study results showed that the instrument Posições frente ao Diagnóstico de Enfermagem (PDE), the name given to the version of the Positions on Nursing Diagnosis adapted for use in Brazil, possessed good psychometric properties.

As nursing diagnosis is considered part of the $N P$, it was admitted that the $P D E^{(8)}$ could be adapted to assess attitudes towards the nursing process. Face validity analysis of the 20 pairs of adjectives in the PDE, developed before the present study, confirmed that they could be applied to assess attitudes towards the NP as a whole. In view of the lack of an instrument for this purposes and the importance of attitudes towards NP as a variable in research on the theme, the aim in this study was to estimate the psychometric properties of the adaptation of the $P D E^{(8)}$ to assess nursing staff members' attitudes towards the NP.

\section{Method}

This methodological research is part of a broader and ongoing project to assess characteristics of the nursing process in institutions affiliated with the São Paulo State Health Secretariat (Project SAE/SES). The non-probabilistic sample included 973 nursing assistants and 632 baccalaureate nurses from 35 hospitals and outpatient clinics affiliated with the São Paulo State Health Secretary.

Data were self-reported. The participants answered a questionnaire with personal data, education, work, knowledge and degree of contact with the NP and the research instrument, which was denominated Posições sobre o Processo de Enfermagem (PPE).

In the instrument to characterize the respondents, data were investigated about knowledge and contact with the NP. Therefore, the expression "NCS" was chosen, which is the most common way for nursing professionals to refer to the NP in Brazil. The participants chose among 'none', 'little', 'moderate' or 'a lot' to indicate how much they knew about 'NCS in general', about 'interview and physical examination', 'nursing diagnosis', 'nursing 
prescription', and about 'nursing evolution'. Knowledge about the NP was assessed with the help of five items, whose combined scores could range between five and 20. The five items showed good reliability in the sample $(\mathrm{N}=1526$; Cronbach's alpha $=0.883)$. The degree of contact with the NP was estimated through the participants' self-report on how much contact they had with the theme 'NCS' in the last three years, considering reading activities on the theme, participation in classes or courses on the them, participation in specific events, use in clinical practice and research activities. For each of the five items, the answer scale ranged from 'nothing' to 'little', 'moderate' or 'a lot'. Thus, the degree of contact with the NP was assessed with the help of five items, whose combined scores could vary between five and 20. The five items showed good reliability in the sample $(\mathrm{N}=1543$; Cronbach's alpha $=0.822)$. These variables were analyzed by the total score on the five items and, the higher the score, the more intense the knowledge or contact with the NP.

In the $P P E$, the respondents were asked to score how they felt towards the NCS, using the same 20 pairs of adjectives used in the instrument for the attitude towards nursing diagnoses. A general statement was included about the extent to which the respondents were in favor of the NCS, so as to estimate the validity of the adaptation. Each subject's answers on each of the 20 items in the PPE could range between 1 and 7, the total instrument score between 20 and 140 and, the higher the score, the more favorable the participant's attitude. The PPE includes 11 inverted items, which were corrected in the database before the analyses. All results will be presented with a score range from 1 to 7 , that is, from the most unfavorable to the most favorable attitude. In a study(9), the authors propose that items with scores $\geq 5.5$ be analyzed as strongly in favor, while items with a mean score $\leq 4.5$ relate to more unfavorable positions.

$P P E$ answers were processed and submitted to confirmatory factor analysis (CFA) and the calculation of internal consistency coefficients.

For CFA, structural equation models were applied to the 20 PPE items to confirm the existence of three domains to assess attitudes towards the NP, as evidenced in the validation study of the Brazilian $P D E$ version ${ }^{(8)}$. CFA is analogue to exploratory factor analysis, but researchers impose restrictions according to their knowledge about what they are studying(10-12). The model produced by the researchers' knowledge is confronted with empirical evidence. In this study, the model was adjusted, considering each item as an ordinal categorical variable. When an appropriate model is obtained for interpretation, this confirms the validity of the scale.

The reliability of the PPE was estimated through the Cronbach's alpha coefficient of the answers of subjects who replied to all items.

The project was submitted to the Institutional Review Board at the University of São Paulo School of Nursing for evaluation of ethical aspects (Process $856 / 2009$ ) and to the São Paulo State Health Secretary Health Service Coordination Office (Letter 189/2009) for authorization. Approval was obtained at both levels. One of the researchers or research assistants individually and personally presented the consent form to the subjects and was available for any clarifications. All participants signed the consent term after clarifications.

\section{Results}

Out of 1,605 participants, $86.9 \%$ were female, with a mean age of 44.1 years $(S D=9.6), 52.3 \%$ worked at general hospitals and had been working at the institutions for an average ten years. About twenty percent of the baccalaureate nurses worked in leading functions. As regards nursing education, $10.6 \%$ of the assistants had finished an undergraduate program and $4.4 \%$ a specialization course. Out of 632 baccalaureate nurses, $9.2 \%$ indicated they had never taken a specialization program, 12 baccalaureate nurses held an M.Sc. and two a Ph.D. in nursing, 43 were taking a specialization course, 15 a Master's and four a doctoral program.

Knowledge about the NP and the degree of contact with the theme was assessed with the help of five questions each. Answers to the questions could range between 1 (none) and 4 (a lot) and, the closer to four, the greater the knowledge or degree of contact with the NP. In all references to the NP, the expression NCS was used, as that is the usual expression in Brazilian nursing. As regards knowledge about NCS, the mean score was 2.8 $(\mathrm{SD}=0.7)$ for the sample of nursing assistants and 3.2 $(S D=0.5)$ for the baccalaureate nurses. The mean score on the five questions about the degree of contact with NCS corresponded to $2.1(S D=0.7)$ for the assistants and $2.5(\mathrm{SD}=0.6)$ for the baccalaureate nurses.

Some subjects did not answer some PPE items and the researchers decided not to use statistical techniques to complete missing answers. Therefore, for each result, the number of valid answers will be indicated. 
The total PPE score ranged between 20 and 140 for the total sample, for nursing assistants and for baccalaureate nurses. The total mean score, considering all respondents $(\mathrm{N}=1489)$, corresponded to 112.37 ( $S D=22.28)$; for the nursing assistants $(\mathrm{N}=889)$, the total mean score was $111.04(\mathrm{SD}=23.15)$ and, for the baccalaureate nurses $(\mathrm{N}=600), 114.34$ $(\mathrm{SD}=20.80)$.

The lowest mean score on the PPE items was for the item rotineiro/criativo (3.98) and the highest for sem importância/importante (6.15) when considering the total sample. Among the nursing assistants, the result was similar to the total sample, as the lowest score (3.96) was for the item rotineiro/criativo and the highest (6.07) for sem importância/importante. The baccalaureate nurses also revealed the lowest score for rotineiro/criativo (4.01) and the highest for the item negativo/positivo (6.32).
The mean score for items with highly favorable scores was $\geq 5.5$, while that for scores that approached more unfavorable positions was $\leq 4.5^{(9)}$. The pair rotineiro/criativo showed a mean score $<4.5$, in the total sample as well as among nursing assistants and baccalaureate nurses. The following items showed mean scores >5.5: não significativo/significativo, sem valor/valioso, negativo/positivo, bobo/inteligente, dificultador/facilitador, inválido/válido, insignificante/ significante, irrelevante/relevante, não recompensador/ recompensador, inconveniente/conveniente, inaceitável/aceitável, ruim/bom and sem importância and importante, in the three groups of respondents.

Table 1 displays the CFA results based on the proposed theoretical model. Three factors were identified, consisting of 13,5 and 2 items. These three factors also constitute a more general factor, which will be called single factor (secondary level) here.

Table 1 - Confirmatory Factor Analysis of the PPE, São Paulo, SP, Brazil, 2011

\begin{tabular}{|c|c|c|c|c|c|c|c|}
\hline & \multicolumn{2}{|c|}{$\begin{array}{c}\text { Baccalaureate nurses and } \\
\text { assistants }(\mathrm{N}=1489)\end{array}$} & \multicolumn{2}{|c|}{ Nursing assistants $(\mathrm{N}=889)$} & \multicolumn{3}{|c|}{ Baccalaureate nurses $(\mathrm{N}=600)$} \\
\hline & $\begin{array}{c}\text { Factors } \\
\text { Standardized } \\
\text { factor loading }\end{array}$ & $\begin{array}{l}\text { Standard } \\
\text { error }\end{array}$ & $\begin{array}{l}\text { Standardized } \\
\text { factor loading }\end{array}$ & $\begin{array}{l}\text { Standard } \\
\text { error }\end{array}$ & $\begin{array}{l}\text { Standardized } \\
\text { factor loading }\end{array}$ & $\begin{array}{l}\text { Standard } \\
\text { error }\end{array}$ & p-value \\
\hline \multicolumn{8}{|l|}{ Factor 1} \\
\hline Importante & 0.84 & 0.01 & 0.84 & 0.01 & 0.83 & 0.02 & $<0.001$ \\
\hline Bom & 0.86 & 0.01 & 0.86 & 0.01 & 0.84 & 0.02 & $<0.001$ \\
\hline Aceitável & 0.88 & 0.01 & 0.88 & 0.01 & 0.88 & 0.01 & $<0.001$ \\
\hline Conveniente & 0.86 & 0.01 & 0.86 & 0.01 & 0.85 & 0.01 & $<0.001$ \\
\hline Recompensador & 0.76 & 0.01 & 0.75 & 0.02 & 0.78 & 0.02 & $<0.001$ \\
\hline Relevante & 0.90 & 0.01 & 0.91 & 0.01 & 0.89 & 0.01 & $<0.001$ \\
\hline Significante & 0.91 & 0.01 & 0.90 & 0.01 & 0.92 & 0.01 & $<0.001$ \\
\hline Válido & 0.88 & 0.01 & 0.86 & 0.01 & 0.91 & 0.01 & $<0.001$ \\
\hline Realista & 0.81 & 0.01 & 0.84 & 0.01 & 0.77 & 0.02 & $<0.001$ \\
\hline Inteligente & 0.88 & 0.01 & 0.89 & 0.01 & 0.87 & 0.01 & $<0.001$ \\
\hline Positivo & 0.87 & 0.01 & 0.89 & 0.01 & 0.83 & 0.02 & $<0.001$ \\
\hline Valioso & 0.89 & 0.01 & 0.89 & 0.01 & 0.88 & 0.01 & $<0.001$ \\
\hline Significativo & 0.89 & 0.01 & 0.90 & 0.01 & 0.87 & 0.02 & $<0.001$ \\
\hline \multicolumn{8}{|l|}{ Factor 2} \\
\hline Claro & 0.71 & 0.02 & 0.72 & 0.02 & 0.68 & 0.02 & $<0.001$ \\
\hline Agradável & 0.73 & 0.01 & 0.77 & 0.01 & 0.66 & 0.02 & $<0.001$ \\
\hline Confortável & 0.82 & 0.01 & 0.84 & 0.01 & 0.79 & 0.02 & $<0.001$ \\
\hline Fácil & 0.50 & 0.02 & 0.56 & 0.02 & 0.40 & 0.04 & $<0.001$ \\
\hline Facilitador & 0.86 & 0.01 & 0.86 & 0.01 & 0.87 & 0.02 & $<0.001$ \\
\hline \multicolumn{8}{|l|}{ Factor 3} \\
\hline Criativo & 0.83 & 0.02 & 0.85 & 0.03 & 0.79 & 0.03 & $<0.001$ \\
\hline Forte & 0.52 & 0.02 & 0.50 & 0.03 & 0.55 & 0.03 & $<0.001$ \\
\hline \multicolumn{8}{|l|}{ General factor } \\
\hline factor 1 & 0.95 & 0.01 & 0.95 & 0.01 & 0.94 & 0.01 & $<0.001$ \\
\hline factor 2 & 0.96 & 0.01 & 0.98 & 0.01 & 0.94 & 0.01 & $<0.001$ \\
\hline factor 3 & 0.88 & 0.02 & 0.83 & 0.03 & 0.95 & 0.03 & $<0.001$ \\
\hline
\end{tabular}


The validity of the PPE scale was also verified by correlated the mean scores on the 20 items and the answers to the general statement "I am in favor of the systemization of nursing care", measured on a single seven-point scale. The hypothesis was that the scale scores would be positively correlated with the general statement. The correlation between the general statement and each of the items and with the total (twenty-items) scale was positive (Spearman rho $=0.55)$ and statistically significant $(p<0.001)$.

As regards the reliability of the PPE, Cronbach's alpha coefficient was used to measure the internal consistency of the scale. To maintain the items on a scale, the criteria to remove inconsistent items are: correlation between each item and the score (when the correlation is very low or negative, the item has to be excluded) and the increase in the alpha coefficient when the item is removed (only when this increase is important)(13).

The reliability of the instrument was verified as it is an adapted version. Estimating the reliability of an instrument is recommended whenever it is used, as it always depends on the sample it is applied $\mathrm{in}^{(13)}$.

Table 2 - Internal consistency analysis results of PPE, São Paulo, SP, Brazil, 2011

\begin{tabular}{|c|c|c|c|c|c|c|}
\hline \multirow[b]{2}{*}{ Items } & \multicolumn{2}{|c|}{ Total sample } & \multicolumn{2}{|c|}{ Assistants } & \multicolumn{2}{|c|}{ Baccalaureate nurses } \\
\hline & Correlation & $\begin{array}{l}\text { Alpha if the item } \\
\text { is excluded }\end{array}$ & Correlation & $\begin{array}{l}\text { Alpha if the item } \\
\text { is excluded }\end{array}$ & Correlation & $\begin{array}{l}\text { Alpha if the item } \\
\text { is excluded }\end{array}$ \\
\hline Ambíguo/claro & 0.581 & 0.946 & 0.595 & 0.950 & 0.557 & 0.939 \\
\hline Não significativo/significativo & 0.747 & 0.944 & 0.755 & 0.947 & 0.730 & 0.937 \\
\hline Desagradável/agradável & 0.597 & 0.946 & 0.646 & 0.949 & 0.521 & 0.940 \\
\hline Fraco/forte & 0.632 & 0.945 & 0.617 & 0.950 & 0.654 & 0.937 \\
\hline Sem valor/valioso & 0.741 & 0.944 & 0.763 & 0.947 & 0.698 & 0.937 \\
\hline Negativo/positivo & 0.756 & 0.944 & 0.761 & 0.948 & 0.745 & 0.937 \\
\hline Bobo/inteligente & 0.765 & 0.943 & 0.767 & 0.947 & 0.760 & 0.936 \\
\hline Desconfortável/confortável & 0.708 & 0.944 & 0.737 & 0.948 & 0.669 & 0.937 \\
\hline Difícil/fácil & 0.373 & 0.950 & 0.437 & 0.953 & 0.293 & 0.945 \\
\hline Não realista/realista & 0.681 & 0.945 & 0.670 & 0.949 & 0.702 & 0.937 \\
\hline Dificultador/facilitador & 0.731 & 0.944 & 0.740 & 0.948 & 0.713 & 0.936 \\
\hline Inválido/válido & 0.792 & 0.943 & 0.810 & 0.947 & 0.757 & 0.936 \\
\hline Insignificante/significante & 0.786 & 0.943 & 0.789 & 0.947 & 0.778 & 0.936 \\
\hline Irrelevante/relevante & 0.778 & 0.943 & 0.761 & 0.947 & 0.810 & 0.935 \\
\hline Não recompensador/recompensador & 0.717 & 0.944 & 0.753 & 0.947 & 0.669 & 0.937 \\
\hline Inconveniente/conveniente & 0.786 & 0.943 & 0.800 & 0.947 & 0.765 & 0.936 \\
\hline Inaceitável/aceitável & 0.769 & 0.944 & 0.790 & 0.947 & 0.732 & 0.937 \\
\hline Ruim/bom & 0.801 & 0.943 & 0.803 & 0.947 & 0.795 & 0.936 \\
\hline Rotineiro/criativo & 0.374 & 0.952 & 0.350 & 0.956 & 0.416 & 0.945 \\
\hline Sem importância/importante & 0.754 & 0.944 & 0.771 & 0.947 & 0.722 & 0.937 \\
\hline
\end{tabular}

Cronbach's alpha of the 20-item instrument corresponded to 0.954 for the total sample $(\mathrm{N}=1489)$, 0.957 for the nursing assistants $(\mathrm{N}=889)$ and 0.950 for the baccalaureate nurses $(\mathrm{N}=600)$, indicating good internal consistency.

The item rotineiro/criativo showed the lowest correlations for the general sample (0.374), for the nursing assistants (0.350) and for the baccalaureate nurses (0.416), as well as difícil/fácil, with 0.373 for the general sample, 0.437 for the nursing assistants and 0.293 for the baccalaureate nurses. Removing these items would represent a very small increase in the alpha coefficient (Table 2) and would hamper comparisons with other studies. Therefore, the researchers decided to maintain all items in the scale.

\section{Discussion}

The adaptation of an instrument on positions on nursing diagnosis to assess positions towards the NP was based on the premise of theoretical coherence between positions on nursing diagnosis and the NP. The nursing diagnosis, considered part of the NP, derives from the same conceptual perspective ${ }^{(14)}$. Nevertheless, the particularities in each phase of the NP should be heeded.

The original instrument contains general adjectives than can be applied to the NP as a whole, and not just to one of its phase ${ }^{(14)}$. Hence, the PPE should maintain the psychometric properties observed in the instrument Posições frente ao Diagnóstico de Enfermagem $(P D E)^{(8)}$. 
The results of the application of PPE to baccalaureate nurses and nursing assistants confirmed the premise about the three-factor structure, similar to the $P D E$ factors. The $P P E$ instrument adapted in this study to assess the Nursing Process maintained the factor structure of the PDE version validated for Brazilian Portuguese(8).

In the Brazilian PDE study(8), one factor explained $50 \%$ of the variance. The authors chose the three-factor solution, which explained $61.3 \%$ of the variance, because the result is compatible with classical observations on attitude assessment instruments ${ }^{(15)}$. These observations indicated that, independently of the concepts studied and the subjects whose attitudes were analyzed, three dominant orthogonal factors always appeared: one "evaluation" factor (represented by items like bom-ruim), one "power" factor (represented by items like strongweak) and one "activity" factor (represented by items like facilitador-dificultador) ${ }^{(8)}$. In this study, the three factors present in classical attitude theory were observed(15). Like in the adaptation study of the instrument to assess positions on nursing diagnosis( ${ }^{(8)}$, factor 1 corresponds to the "evaluation" factor(15), factor 2 to the "activity" factor $^{(15)}$ and factor 3 to the "power" factor ${ }^{(15)}$.

The North American PND study ${ }^{(7)}$, involving a sample of 127 baccalaureate nurses, included factor analysis through different methods and the authors defined that the instrument contained only one dimension, which explained $80.8 \%$ of the variance. In their publication, however, they did not include the factor loading table, which impedes appropriate comparisons with Brazilian research $^{(8)}$. The premise that attitude scales tend to be one-dimensional may have guided the factor analysis in the North American study, enforcing the one-factor solution ${ }^{(8)}$.

The study that used the PPE scale among nurse managers identified three factors through factor analysis with varimax rotation ${ }^{(14)}$. The author interpreted that all items belonged to the evaluation group. Factor 1 , which explained $58.4 \%$ of the variance, was characterized as 'relevance', factor 2, explaining 6.4\%, was associated with 'putting the NP in practice' and factor 3, which explained 5.3\%, was characterized as 'cooperation'(14).

The present study findings coincided with another study among nurse managers ${ }^{(14)}$, except for the items: desagradável/agradável, fraco/forte, desconfortável/ confortável, difícil/fácil, não realista/realista, rotineiro/ criativo, which were maintained in different factors.

To further explore the findings and encourage discussions, the factor loadings will be discussed in detail. The items não recompensador/recompensador, inválido/válido, fraco/forte showed a higher factor loading among nursing assistants when compared to baccalaureate nurses. The items não realista/ realista, negativo/positivo, não significativo/ significativo, ambíguo/claro, desagradável/agradável, desconfortável/confortável, difícil/fácil, rotineiro/ criativo, on the other hand, presented a higher factor loading for baccalaureate nurses when compared to the scores of nursing assistants. For the sake of future research, it should be checked whether these items behave differently among baccalaureate nurses and nursing assistants, and identified how these subjects understand their specific competences regarding the application of the NP in clinical practice.

Another validity measure was estimated by correlating the items with the general statement on being in favor of NCS. For that study, the mean item correlation coefficient with the general statement (Spearman rho=0.55; $\mathrm{p}<0.001$ ) was slightly lower than in the $P D E$ adaptation study ${ }^{(8)}$ (Spearman rho= $0.64 ; \mathrm{p}<0.001)$. The researchers consider that these coefficients illustrate the validity of the instrument adapted to the NP. The original PND(7) was not submitted to this type of analysis.

In the present study, the smallest correlation with the general statement was for the items rotineiro/ criativo and difícil/fácil. According to research results, in baccalaureate nurses' perspective, the NP is understood as a routine and mechanic activity ${ }^{(16-18)}$. The discourse of a nursing technician identifies the nursing prescription as a routine, something that is almost similar for everyone ${ }^{(5)}$. According to some subjects, NCS is frequently mechanic and routine, aggravated by insufficient nursing staff numbers, task division, disagreeing, inconsistent or mismatched information, discontinuities and excessive bureaucratization ${ }^{(16-17)}$.

According to reports by nursing technicians, their initial education did not include NCS and, in learning, nursing care was emphasized ${ }^{(5)}$. Nurses' lack of knowledge is the main reason that makes these professionals not practice it in their clinical practice ${ }^{(19)}$. It was highlighted in a study that, although most baccalaureate nurses learned and executed the phases of the NP in their undergraduate program, considerable difficulties were reported in clinical practice ${ }^{(19)}$. This reveals the insufficient theoretical and practical preparation of nurses and other nursing team members to accomplished NCS when they finish their basic education(19). Besides aspects related to knowledge about the NP, health institutions' 
organizational characteristics and conditions (adopted care model, patient-nursing ratio, expectations on the role of baccalaureate nurses and nursing, for example) can contribute to the perception that the NP is difficult.

The highest correlation coefficients were found between the items significativo/significativo, negativo/ positivo, inválido/válido and the general assertion. Although some studies report on difficulties and resistance in the implementation process of the NP in health institutions ${ }^{(17-18,20)}$, since 1986, when the Law on Professional Nursing Practice ${ }^{(21)}$ was issued, in theory, the NP is part of baccalaureate nurses' role, which may explain why it figures as an ideal to be achieved, with significant, positive and valid aspects, despite the distance among academic knowledge, know-how and legislation in nursing(22).

The reliability of the PPE in this study was assessed with the help of Cronbach's alpha, which corresponded to 0.954 for the general sample, 0.957 for the nursing assistants and 0.950 for the baccalaureate nurses, indicating good internal consistency. In the Brazilian $P D E$ validation study, Cronbach's alpha for the sample of 400 baccalaureate nurses and undergraduate nursing students equaled 0.94, considering the 20 instrument items; for the sub-sample of 100 baccalaureate nurses, the coefficient was equal to 0.89 before and 0.93 after a nursing diagnosis course ${ }^{(8)}$. In the development study of the original scale ${ }^{(7)}$, like in the study that used the $P D E$ to measure baccalaureate nurses' attitudes towards the ND before and after the start of nursing diagnosis registers in patients' files, Cronbach's alpha corresponded to 0.97 . In the study among nurse managers ${ }^{(14)}$ using the $P P E$, Cronbach's alpha equaled 0.955 for factor $1,0.844$ for factor 2 and 0.807 for factor 3 .

In this study, the reliability of the adapted scale bordered on that of original scale and that reported in the study among nurse managers ${ }^{(14)}$. Hence, the reliability of the PPE in this study was very good for the set of baccalaureate nurses and nursing assistants' answers (alpha $=0.954$ ) and none of the estimates supported the withdrawal of any item. The 20 scale items were maintained. The factor analysis, including one more general secondary-level factor, comprising three classical attitude factors $^{(15)}$ and the reliability coefficient of 0.954 for the total instrument support the calculation of the general instrument score by adding up the item scores.

The study limitations are due to the fact that a nonprobabilistic sample was used. Although the instrument addresses baccalaureate nurses and nursing assistants' attitudes towards the NP, instead of their responsibilities and tasks in its implementation, further research is needed to identify whether the instrument items behave differently according to the respondent's professional category.

\section{Conclusion}

In this study, an instrument was adapted to assess baccalaureate nurses and nursing assistants' attitudes on the NP. The results indicated that the validity and reliability of the instrument Posições sobre o Processo de Enfermagem are appropriate. Nevertheless, in future studies, it should be verified whether the items behave differently according to the respondents' professional category and how the PPE behaves when applied among nursing students.

\section{References}

1. Conselho Federal de Enfermagem (COFEN) (BR). Resolução COFEN 358/2009. Dispõe sobre a sistematização da assistência de enfermagem - SAE nas instituições de saúde brasileiras [legislação na Internet]. Brasília; 2009 [acesso 11 nov 2011]. Disponível em: http://site.portalcofen.gov.br/node/4384

2. Von Krogh G, Nåden D. Implementation of a documentation model comprising nursing terminologiestheoretical and methodological issues. J Nurs Manage. 2008;16(3):275-83.

3. Miller E. How to make nursing diagnoses work. administration and clinical strategies. Norwalk: Apleton Lange; 1989.

4. Pimenta CAM. Atitudes de doentes com dor crônica frente à dor [tese] São Paulo: Escola de Enfermagem da Universidade de São Paulo; 1999.

5. Cruz AMP, Almeida MA. Competências na formação de Técnicos de Enfermagem para implementar a Sistematização da Assistência de Enfermagem. Rev Esc Enferm USP. 2010;44(4):921-7.

6. Kenney JW. Relevance of theory-based nursing practice. In: Christensen PJ, Kenney JW, editors. Nursing process: application of conceptual models. 4th ed. St. Louis: Mosby; 1995. p. 3-23.

7. Lunney $M$, Krenz MA. An instrument to measure attitudes toward nursing diagnosis. In: Carroll-Johnson RM, Paquette $M$, editors. Classification of Nursing Diagnoses Proceedings of the Tenth Conference of North American Nursing Diagnosis Association. San Diego: Lippincott; 1992. p. 389-90.

8. Cruz DALM, Hayashi APM, Oliva APV, Corrêa CG. Adaptação e validação do instrumento "Positions on 
nursing diagnosis" para a língua portuguesa. Rev Bras Enferm. 2006;59(2):163-7.

9. Cruz DALM, Kitazulo RC, Pimenta CAM, Lima AFC, Gaidzinski RR. Atitudes frente ao diagnóstico de enfermagem durante a implementação de classificação de diagnósticos. Ci Cuidado Saúde. 2006;5(3):281-8.

10. Long JS. Confirmatory factor analysis. In: Alisson PD. Quantitative Applications in the Social Sciences. London: SAGE University; 2002.

11. Hair Jr JF, Anderson RE, Tatham RL, Black WC. Multivariate data analysis. 5th ed. New Jersey: Prentice Hall; 1998.

12. Johnson RA, Wichern DW. Applied multivariate statistical analysis. 4th ed. New Jersey: Prentice Hall; 1998.

13. Nunnally JC, Bernstein IH. Psychometric theory. New York: McGraw-Hill; 1994.

14. Leite JEL. Viabilidade do processo de enfermagem no contexto hospitalar: perspectiva gerencial [dissertação]. Natal: Departamento de Enfermagem da Universidade Federal do Rio Grande do Norte; 2011.

15. Osgood CE. Cross-cultural comparability in attitude measurement via multilingual semantc differentials. In: Fishbein $M$, editor. Readings in attitude theory and measurement. New York: John Wiley; 1967. p. 108-16. 16. Nascimento KC, Backes DS, Koerich MS, Erdmann AL. Sistematização da assistência de enfermagem: vislumbrando um cuidado interativo, complementar e multiprofissional. Rev Esc Enferm USP. 2008;42(4):643-8. 17. Castilho NC, Ribeiro PC, Chirelli MQ. A implementação da sistematização da assistência de enfermagem no serviço de saúde hospitalar do Brasil. Texto Contexto Enferm. 2009;18(2):280-9.

18. Ledesma-Delgado ME, Mendes MMR. The nursing process presented as routine care actions: building its meaning in clinical nurses' perspective. Rev. Latino-Am. Enfermagem. 2009;17(3):328-34.

19. Takahashi AA, Barros ALBL, Michel JLM, Souza MF. Dificuldades e facilidades apontadas por enfermeiras de um hospital de ensino na execução do processo de enfermagem. Acta Paul Enferm. 2008;21(1):32-8.

20. Carvalho EC, Kusumota L. Processo de enfermagem: resultados e consequências da utilização para a prática de enfermagem. Acta Paul Enferm. 2009;22(EspecialNefrologia):554-7.
21. Lei n. 7.498, de 25 de junho de 1986 (BR). Dispõe sobre a Regulamentação do Exercício da Enfermagem e dá outras providências. In: Conselho Regional de Enfermagem de São Paulo (COREN-SP). Documentos básicos de enfermagem: enfermeiros, técnicos e auxiliares. São Paulo; 2001. p. 36-41.

22. Koerich MS, Backes DS, Nascimento KC, Erdmann AL. Sistematização da assistência: aproximando o saber acadêmico, o saber-fazer e o legislar em saúde. Acta Paul Enferm. 2007;20(4):446-51. 